\title{
Surveillance \&
Questions of Surveillance
}

\section{David Murakami Wood}

Department of Sociology, Queen’s University, Canada. dmw@queensu.ca

The contents of this issue of Surveillance \& Society, the first in our seventh volume, bring up a number of important questions for researchers working in the field, or indeed anyone interested in surveillance.

The first is the question of history and context. Recent years have shown a remarkable rise in the consideration of both surveillance in historical contexts as well as the historical roots of contemporary surveillance. It is entirely appropriate that the mammoth new work by Alfred W. McCoy, Policing America's Empire (2009), should be the current must-read as we publish Keith Guzik's article on the tactics and strategies employed by the United States in its 'War on Terrorism'. Whilst Guzik provides both a survey and a critique of the contemporary US 'surveillance state', McCoy's book contextualises this (and the many other articles and books being produced on this theme) in the US struggle for control in the Philippines and the legacy that this created for both the post-colonial Philippines and for both external and internal control by the US state to the present day. There will be a full review of McCoy's work in a forthcoming issue; in the meantime, enjoy Keith Guzik's excellent piece.

The USA's northern neighbour, Canada, has long enjoyed a reputation of being in many ways a more ethical version of the 'frontier' state. Now, the actions of a government deciding to stand with the USA for better or worse in military action in the 'War on Terrorism' are challenging that reputation as several pieces in previous issues have demonstrated. But it becomes debatable, reading Shelly Ikebuki Ketchell's piece, which analyses the control of the Japanese Canadian population in WW2, whether Canada ever really had any deeper-rooted ethical foundations - at least when it comes to surveillance. This too is reinforced by a recent book, in this case a new work by Scott Thompson and Gary Genosko (2009), Punched Drunk, which builds on articles published here and elsewhere to provided a detailed picture of the control of alcohol (and more importantly of drinkers) in Ontario in the Twentieth Century. Whether based on wartime fear or the moralistic good intentions of anti-alcohol campaigners, particular systems, technologies and practices of surveillance helped define the national and provincial identities of Canada, as they did with just about every society on which research has been conducted.

In the contemporary situation, one can also see such characteristics. In the case of the $\$ 1 B n$ security preparations for Vancouver Olympic Winter Games in 2010, the only distinctive thing about Canada's approach appears to be the belief that it is different. The actual practice is just as anxious, fearful and repressive as we have come to expect from such mega-events in whichever country they are held. In this case, following a recent conference in Vancouver, a number of surveillance studies scholars have taken the unusual step of releasing a critical but constructive statement on the Games ${ }^{1}$. I would encourage all scholars in the field to read it and to consider signing.

1 The Vancouver Statement http://www.surveillanceproject.org/Vancouver Statement 
This highlights another question, which is also addressed in a very different way by Nicholas Holm in his piece on conspiracy theory and surveillance, which is the nature of our personal orientation to the phenomenon we study. Everyone who studies surveillance has probably at one time or another been called 'paranoid' or 'a conspiracy theorist', and one response to this is to bury ourselves in solid empirical work and the accumulation of 'evidence'. But then these questions of responsibility and what to do with this knowledge appear - can we (or perhaps even must we) be activists and scholars? And how much are we ourselves afraid of examining the roots of our own interest in a subject considered automatically by many a 'common sense' view to be either the domain of the tin-foil hated crackpot, or alternatively and increasingly common these days, to be not paranoid or sceptical enough?

The fuzzy edges of surveillance, paranoia and conspiracy, also bring up, once again, the question of the limits of this thing we call 'surveillance' and of the field of 'Surveillance Studies' itself. This is a question that will tend to interpose itself at some point in the life of any transdisciplinary research field as it expands, becomes more successful and acquires a life larger than those who originated it. It is particularly the case when various authors, myself included, have made statements along the lines of describing surveillance as endemic, everywhere, central, pervasive, ubiquitous or any number of other totalising adjectives. Beyond what in retrospect seems to have been a clumsy attempt by me to start a debate about these issues - see the response from Hier and Greenberg in this issue to a review article in issue 6(1) - it is the articles in this issue that implicitly and rather more constructively carry forward the question and by implication carry forward challenges both for the other authors in this very issue as well as those throughout the field.

In this context, Christopher Gad and Peter Lauritsen tackle an issue which has still not been addressed to any great extent within the field (although see: Donaldson and Wood, 2004), that of the messiness and categorical impurity which defines much of the real world operation of surveillance across the boundary of human and non-human. In their study of fisheries surveillance, the surveillance that is carried out has very little to do with 'subjectivity' or 'personhood' which are often held to at the core of what surveillance is all about (see e.g.: Lyon 2007, ch.2). Instead we have an actor-network that involves limited views on humans, boats, weather and fish of varying degrees of intensity. For me, the immediate questions that come out of this are that if he human is not central, what is the (data) subject here? And ultimately, if surveillance seems to be implicated at almost every level and with nearly every kind of action, in all societies and situations, what kinds of social or sociotechnical processes are not surveillance, or at least not bound-up with surveillance?

Finally, we have a piece by Patrick O'Byrne and Dave Holmes which takes what is in Surveillance Studies, the more common alternative to the Actor-Network Theory used by Gad and Lauritsen: the Deleuzian notion, via Haggerty and Ericson (2000), of the 'surveillant assemblage'. They arrive at the assemblage through a consideration of the inadequacy of Foucauldian narratives to describe the surveillance of sexually transmitted diseases. The medical too informs an intriguing addition to this issue, Jan Knoetze and Brent Meistre's The 50-Minute Hour, a video piece by dealing with surveillance and psychiatric techniques and narratives. Our next issue will be entirely devoted to new media, performance and art around surveillance, so this piece is an intriguing taster in addition to its own undoubted qualities.

\section{References}

Donaldson, Andrew and David Wood. 2004. Surveilling Strange Materialities: Categorisation in the Evolving Geographies of FMD Biosecurity in the UK. Environment and Planning D: Society and Space, 22(3): 373-391.

Haggerty, Kevin D. and Richard V. Ericson. 2000. The Surveillant Assemblage. British Journal of Sociology, 51(4): 605-622. Lyon, David. 2007. Surveillance Studies: An Overview. Cambridge: Polity Press.

McCoy, Alfred W. 2009. Policing America's Empire: The United States, the Philippines and the Rise of the Surveillance State. Madison WI: University of Wisconsin Press.

Thompson, Scott and Gary Genosko. 2009. Punched Drunk: Alcohol, Surveillance and the LCBO 1927-1975. Nova Scotia: Fernwood. 